\title{
Combining or Separating Forward and Reverse Logistics
}

Herbert-Hansen, Zaza Nadja Lee; Larsen, Samuel; Nielsen, Anders; Groth, Anders; Gregersen, Nicklas Gregers; Ghosh, Amartya

Published in:

International Journal of Logistics Management

Link to article, DOI:

10.1108/IJLM-12-2016-0299

Publication date:

2018

Document Version

Peer reviewed version

Link back to DTU Orbit

Citation (APA):

Herbert-Hansen, Z. N. L., Larsen, S., Nielsen, A., Groth, A., Gregersen, N. G., \& Ghosh, A. (2018). Combining or Separating Forward and Reverse Logistics. International Journal of Logistics Management, 29(1), 216-236. https://doi.org/10.1108/IJLM-12-2016-0299

\section{General rights}

Copyright and moral rights for the publications made accessible in the public portal are retained by the authors and/or other copyright owners and it is a condition of accessing publications that users recognise and abide by the legal requirements associated with these rights.

- Users may download and print one copy of any publication from the public portal for the purpose of private study or research.

- You may not further distribute the material or use it for any profit-making activity or commercial gain

- You may freely distribute the URL identifying the publication in the public portal 


\title{
Combining or Separating Forward and Reverse Logistics
}

\author{
Hansen, Zaza; \\ Larsen, Samuel Brüning; \\ Nielsen, Anders ; \\ Groth, Anders ; \\ Gregersen, Nicklas ; \\ Ghosh, Amartya \\ Published in Journal: International Journal of Logistics Management.
}

\begin{abstract}
Purpose - While forward logistics handles and manages the flow of goods downstream in the supply chain from suppliers to customers, reverse logistics (RL) manages the flow of returned goods upstream. A firm can combine reverse logistics with forward logistics, keep the flows separated, or choose a position between the two extremes. The purpose of this paper is to identify the contextual factors that determine the most advantageous position, which the paper refers to as the most advantageous degree of combination.

Design/methodology/approach- The paper first develops a scale ranging from $0 \%$ combination to $100 \%$ combination (i.e. full separation). Second, using contingency theory the paper identifies the contextual factors described in RL-literature that determine the most advantageous degree of combination. The set of factors is subsequently tested using a case study, which applies a triangulation approach that combines a qualitative and a quantitative method.

Findings - Results show six distinct contextual factors that determine the most advantageous degree of combination. Examples of factors are technical product complexity, product portfolio variation, and the loss of product value over time.

Practical implications - For practitioners the scale of possible positions and set of contextual factors constitute a decision making framework. Using the framework practitioners can determine the most advantageous position of the scale for their firm.

Originality/value - Much RL-research addresses intra-RL issues while the relationship between forward and reverse logistics is under-researched. This paper contributes to RL-theory by identifying the contextual factors that determine the most advantageous relationship between forward and reverse logistics, and proposes a novel decision making framework for practitioners.
\end{abstract}

Keywords: Reverse logistics, Reverse supply chain, Case study research, Conceptual development

\section{Introduction}

While the forward supply chain concerns the flow from raw materials to end products and from manufacturer to consumer (Govindan et al. 2015), reverse logistics (RL) concerns the reverse flow, from consumer to manufacturer. RL is defined as 'the process of moving goods from their typical final destination for the purpose of recapturing value, or proper disposal' (Rogers and Tibben-Lembke, 1998, p.2). In this paper the detailed definition by the Reverse Logistics Executive Council (RLEC) is used which states "Reverse logistics is a movement of materials from a typical final consumption in an 
opposite direction in order to regain value or to dispose of wastes. This reverse activity includes take back of damaged products, renewal and enlargement of inventories through product take back remanufacturing of packaging materials, reuse of containers, and renovation of products, and handling of obsolete appliances." Blackburn et al. (2004) and Guide and Van Wassenhove (2003) identified five key RL-processes that guide the movement and determine the value extraction described in RLEC's definition. These five processes are core product acquisition, reverse transportation and inventory management, inspection and disposition, remanufacturing, and remarketing.

Separate logistics flows mean investments in separate physical facilities and systems. A combined flow will typically lead to increased complexity because the two flows differ greatly in nature (Rogers \& Tibben-Lembke, 2001). The reverse flow is uncertain in terms of flow size and the condition of the returned goods, which translates into low standardization levels and more manual labor. Forward logistics, on the other hand, can be standardized to a higher degree and dwells on higher certainty regarding both input condition of the goods and processes. Making the right decision in the configuration of forward and reverse logistics can create substantial value and impacts the firm's bottom-line (Genchev et al., 2011; Jaaron \& Backhouse, 2016; John et al., 2017).

Although the RL-concept has been intensively researched in recent years and from different perspectives (Huscroft et al., 2013a; Huscroft et al., 2013b; Narayana et al., 2014), the decision of whether to combine forward and reverse logistical flows or keep them separated is under-researched (Krikke et al., 2013; Antonyová et al., 2016). Fleischmann et al. (2000) questioned whether or not to combine or separate forward and reverse logistic flows, but since then quantitative models all assume that combined flows are the optimal solution due to the economic advantage of using the same facilities (Difrancesco and Huchzemeir, 2016).The main body of RL-research focuses on optimal network designs through Mixed-Integer Linear Programs (MILP) or similar mathematical models. This paper contributes with a qualitative approach for indicating the appropriate degree of combination and separation of return and forward logistics by introducing a number of contextual factors, which can assist in determining the appropriate degree of combination.

This paper is based on contingency theory which states that a firm need to find the most advantageous degree of combination through an analysis of internal and external factors. This means that the most advantageous course of action for a company is dependent on the situation, and the context (Luthans \& Stewart, 1977). In order to investigate the most advantageous forward and reverse logistical relationship for a firm the paper identifies the contextual factors that determine the most advantageous relationship type. Specifically, the paper focuses on identifying the factors that influence the degree of combination of a firm's forward and reverse logistics. The resulting research question is:

RQ: Which contextual factors determine the most advantageous degree of combination between a firm's forward and reverse logistics?

The paper is structured as follows: Section 2 identifies contextual factors based on a review of RLliterature. Section 3 details the methodology for using a case study to test and refine the identified set of contextual factors. Section 4 presents the case study results. Section 5 presents implications for theory and practice whilst Section 6 provides conclusion, limitations and ideas for future research.

\section{Literature review}

This section develops a typology and identifies contextual factors using the contingency theory perspective. While analysing the reverse logistical flow of a firm, the contingency approach is adopted in order to identify the key factors influencing the degree of combination between the firm's forward and 
reverse logistical flows. These influencing factors can be thought of as contingency variables which represent the firm's situation in an external business environment (Zeithaml et al., 1988). Moreover, the contingency approach also emphasizes the fact that all closed loop supply chain systems are not identical and differ from firm-to-firm (Guide et al., 2003).

\subsection{A typology of forward and reverse logistics configurations}

For the scope of this research, a complete combination of the forward and reverse logistic flows is defined as: The sharing of facilities (distribution, sorting, equipment), staff, modes of transportation and management. On the other hand, a complete separation of the forward and reverse logistic flow is defined as: strictly separated facilities, staff dedicated to each operation, transportation modes for each operation only, and two distinct management teams. In this manner physical, technical, and organizational issues are all relevant when investigating the degree of combination an organization has (see for example Hayes et al. (2005) or Slack and Lewis (2002)). The two situations of complete combination and complete separation can be visualized in the form of a scale (see Figure 1), wherein complete combination of the forward and reverse logistical flows correspond to $100 \%$ Combination and complete separation of the forward and the reverse logistical flows correspond to $0 \%$ Combination. We analyze how to place an organization on the scale below during this paper.

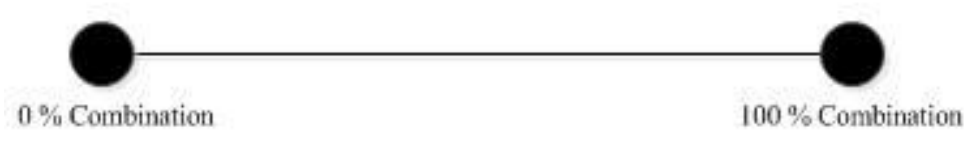

Figure 1: Conceptual scale of the degree of combination

\subsection{The contextual factors that determine the most advantageous degree of combination}

The following section introduces the contextual factors, which determine whether a firm should combine or separate their forward and reverse logistical flows. The identification of the relevant contextual factors and the influence of each of these factors on the degree of combination or separation of the forward and reverse logistical flows will be discussed. The technique applied for uncovering the contextual factors is two-fold; idea generation and screening. Idea generation is done through an extensive literature review, conduced following the guidelines provided by Rowley and Slack (2004). Initially, a search was conducted for all relevant terms related to combination and separation of forward and reverse logistic flows, in the library database of the Technical University of Denmark, also known as DTU Findit. Based on this search criterion, 127 numbers of preliminary articles were selected. A screening process was then carried out, based on the exclusion criteria, leading to 79 focused articles being selected from the preliminary ones. Finally, a detailed examination of the remaining articles led to a final list of 53 articles being chosen for the literature review, which fulfill the criteria for the detailed analysis. Furthermore citation pearl growing was used to identify the main authors within the literature, by investigating relevant articles reference lists.

The screening is done through brainstorming among the authors of the paper along with debates with fellow academics within the reverse logistics community based on the following key criteria. (1) Only papers that addresses RL for manufacturing companies are included, e.g. not papers relating to vendors, retailers, 3PLs and return systems like for example reuse of bottles or batteries a la Danish Returns and (2) Papers that address material recycling were also excluded. Based on the review of the 53 articles the following contextual factors emerged. 


\subsubsection{Strategic Contribution of Reverse Logistics}

Reverse logistics can contribute to the competitiveness of a firm in at least three different ways. First, efficient reverse logistics processes can result in lowering of total supply chain costs for the firm, thereby giving the firm a potential cost advantage (Fisher, 1997; Stock et al, 2002), which can support a strategy of cost leadership (Porter, 1980). Second, these processes can be a significant factor for improving customer service by securing fast repair and return of products to the customer (Larsen and Jacobsen, 2016). This gives the firm a differentiation advantage (Porter, 1980) through the ability to deliver superior service. Third, reverse logistics can contribute to value creation by enabling the firm to reuse or salvage components, sub-assemblies, and products (Mollenkopf \& Closs, 2005). This paper will primarily focus on the first two strategic contributions of reverse logistics of lowering of supply chain costs and improving customer service, thereby following Porter's generic strategies of cost leadership and differentiation. Both the issues of supply chain costs and customer service are viewed by industries as key factors which have an effect on the reverse logistics structures (Huscroft et al, 2013a).

A strategy of cost leadership indicates that a combination strategy will be most beneficial for the firm due to the lower complexity and thus lower cost involved in managing the total supply chain (Blackburn et al, 2004; Fisher, 1997). For firms pursuing a strategy of differentiation based on superior levels of customer service, a separated structure will typically be most beneficial due to the need for a high level of responsiveness within this configuration of the supply chain (Blackburn et al, 2004; Fisher, 1997).

\subsubsection{Skills in managing bi-directional flows}

Rogers \& Tibben-Lembke (2001) conducted a survey of firm's current RL setup at different supply chain positions: manufacturers, wholesalers, retailers and service providers. It was evident that the managers preferred RL to be a separate flow, because in the case of a crisis in the forward flow the equipment and personnel would be prioritized to the forward logistic flow instead of the reverse flow. This is also described as "serving two masters" which is difficult. This is further supported by Bai and Sarkis (2013) who state that it is difficult to manage the role of both supplier (forward flow) and customer (reverse flow). Hence managers who undertake combination of the two flows must be aware and capable of addressing them individually. Bai and Sarkis (2013) further elaborate that it is more complex handling RL than forward logistics due to the differentiation and complexity of products, the unknown volume of return and greater requirements to information management.

According to the case study of a Fortune 500 wholesaler firm presented by Genchev (2009), management's role in the handling of reverse logistic is of utmost importance. The case study showed that simply adding more money to the return process, after receiving complaints from customers, did not solve any problems; rather the additional labor required for RL activities caused more trouble. Based on the case study by Genchev (2009) five major initiatives were derived from the firm, which all related to acknowledging the RL-process as a separate entity and not combined with the forward structure. If management does not possess the capability to control and manage both flows simultaneously, they should follow a separation strategy. Meanwhile, the management's capability of controlling and managing both flows does not directly point towards a separate flow structure, but is a prerequisite if they were to be combined that management has these capabilities.

\subsubsection{Time value of returned goods}

The third key contextual factor is concerned with the time value of the returned products (Blackburn et al, 2004). The time value of the returned product can be evaluated using two factors: the product residual value, PRV, and the marginal value of time, MVT (Gobbi, 2011). The PRV, which refers to the remaining value of the product after the manufacturing or the value creation and the usage or the value consumption 
phase (Kumar et al., 2007; Brodin and Anderson, 2008), is determined by several factors such as condition of the returned product (Guide and Van Wassenhove, 2003; Derimel and Gökçen, 2008), the market for reconditioned products and recycled materials, the cost structure of the recovery process (Prahinski and Kocabasoglu, 2006; Kumar et al., 2007; Stock and Mulki, 2009), and the level of obsolescence (Rose et al., 2002). The product recovery activities are dependent on the PRV with products having high PRV being repaired, remanufactured or refurbished before being resold while products having low PRV are either cannibalized or recycled. The MVT refers to the loss in value per unit of time spent awaiting completion of the recovery process the loss in value per unit of time spent awaiting completion of the recovery process (Blackburn et al., 2004). In case of returned products with high MVT, the firm must try and reduce the processing time required in order to ensure that the residual value extracted from the product is as high as possible.

Thus, in case of returned products with high PRV and high MVT, a combination strategy must be adopted so that the maximum value is extracted from the product, before it re-enters the forward logistics flow. If the returned products have high PRV and low MVT, the firm can adopt either a combined or separated structure. This decision will depend on whether or not the economies of scale can be achieved. If economies of scale are achieved, then the firm should adopt the combination strategy, or else they should implement a separated structure.

\subsubsection{Relative complexity of products}

The fourth key contextual factor is concerned with the complexity of the returned products (Fleischmann et al, 1997). The relative complexity (R.C.) is defined along two dimensions: the absolute complexity of the product and the degree of specialization required in terms of facilities, equipment and personnel to carry out product recovery activities. The absolute complexity of the returned product can be determined from the product composition, i.e. the number of components and materials present in the product and the way in which they have been incorporated into the product design. This absolute complexity of the product can be used to determine the ease of product recovery activities required and the economics of these activities (De Brito and Dekker, 2003). The ease of assessment of the returned product quality and recovery stream will be determined by the second dimension, the degree of specialization at the facilities in terms of the equipment and the employee skills (Fleischmann et al, 1997). The higher the degree of specialization at a facility, the easier will it be for the sorting of the returned products. These two dimensions can be combined to define the contextual factor, R.C., as shown in Figure 2. This factor is relevant because it strongly influences the location of the inspection, sorting and recovery operations of the returned products.

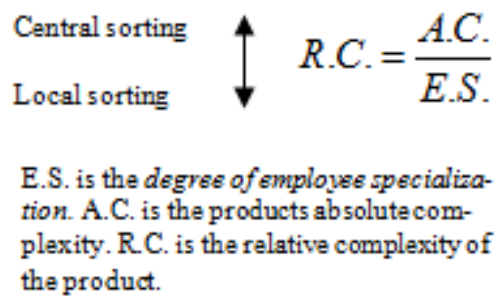

Figure 2: Relative Complexity of Products

When the relative complexity of a returned product is low, i.e. the degree of specialization of the equipment and the personnel are high relative to the absolute complexity, it will be advantageous for the firm to sort the products at separated facilities with the forward and reverse logistics flows combined. In 
the case where the absolute complexity is high in relation to the employees' skills, as it will be advantageous to sort the products at a combined sorting facility, within a separated supply chain.

\subsubsection{Product variation}

Product variation is a way for firms to reach a differentiated customer segment, but doing so also increases the production complexity. The cost-benefit tradeoff of product variety is a debated topic, illustrating the importance of carefully managing the number of product variations offered to the market in order to optimize profits (MacDuffie et al, 1998; Randall \& Ulrich, 2001; ElMaraghy et al, 2012; ElMaraghy et al., 2013; Hu et al., 2011; Lechner et al., 2011; Wan et al., 2012; Brynjolfsson et al., 2011; Serdarasan, 2013).

Several studies have shown the impact of product variability on the forward logistics flow (see for example Thonemann and Bradley (2002) among others), while a few studies have looked into the effect on the reverse logistics flow. Huang and $\mathrm{Su}$ (2012) note that product proliferation directly influences the product return rate, as in the forward flow the products to be produced, though varied, has a defined time frame. On the other hand the return process should be able to handle all different types of products at any point in time, which also increases the need for more skilled employees and also more local storage space, as the square meters needed is not solely depend on return volume but also variation. Furthermore, Asif (2011) identified one of five main groups of uncertainty within RL to be the variety of products in his work on RFID implementation for securing faster information flow in the RL. It is important to address the size of the product portfolio when analyzing whether to combine or separate the forward and reverse flow. Large product portfolios points towards a combined structured, meanwhile smaller product portfolios directs towards a separated structure.

\subsubsection{Volume of returned goods}

Understanding and planning for the volume of returned goods is essential in order to be successful with return logistics, however, the uncertainty of amount and when returned goods arrive are key challenges to do so (see for example Marx-Gomez et al. (2002) and Guide (2000)). Several quantitative models have been presented for forecasting the volume of returned goods (Kumar et al., 2014; Liang et al., 2014; Ma and Kim, 2016; Clottey et al., 2012; Krapp et al., 2013; Li et al., 2010). When Adenso-Diaz et al. (2011) analyses how RSC affect the bullwhip effect the only significant reverse logistics factor is defined as the percentage of units returned. Shankar (2015) also identified volume of products to be entered into the return stream as a key driver of reverse logistic activities for manufacturing firms in India. The volume of returned goods can be used to justify investments in RL-dedicated facilities.

\subsection{Literature summary and theory operationalization}

The six contextual factors and their relation to separation or combination are summarized in Table 1.

Table 1: Summary of the Contextual Factors 


\begin{tabular}{|c|c|c|c|c|c|}
\hline Contextual factor & Description & Measurement/Indicators & Separation & Combination & Key references \\
\hline $\begin{array}{l}\text { F1 } \\
\text { Strategic contribution } \\
\text { of reverse logistics }\end{array}$ & $\begin{array}{l}\text { Reverse logistics can } \\
\text { contribute to the } \\
\text { competitiveness of a firm }\end{array}$ & $\begin{array}{l}\text { Primarily cost advantage and differentiation } \\
\text { advantage. }\end{array}$ & $\begin{array}{l}\text { Strategy of cost } \\
\text { leadership with a cost } \\
\text { efficient supply chain }\end{array}$ & $\begin{array}{l}\text { Differentiation through } \\
\text { superior service in a } \\
\text { responsive supply chain }\end{array}$ & $\begin{array}{l}\text { Fisher, 1997; Stock et al, } \\
\text { 2002; Fisher, 1997; } \\
\text { Huscroft et al, 2013a }\end{array}$ \\
\hline $\begin{array}{l}\text { F2 } \\
\text { Skills in managing } \\
\text { bi-directional (or } \\
\text { combined) flows }\end{array}$ & $\begin{array}{l}\text { Management's skills in } \\
\text { managing combined flows } \\
\text { and the organizational } \\
\text { structure of separation or } \\
\text { combination of the logistic } \\
\text { flows are important success } \\
\text { factors. }\end{array}$ & $\begin{array}{l}\text { Management's experience and knowledge of } \\
\text { handling combined flows and the } \\
\text { organizational structures to support this. }\end{array}$ & $\begin{array}{l}\text { Smaller need for } \\
\text { managerial } \\
\text { competence. }\end{array}$ & $\begin{array}{l}\text { Need for high levels of } \\
\text { managerial competence } \\
\text { in order to manage two } \\
\text { logistical flows } \\
\text { simultaneously }\end{array}$ & $\begin{array}{l}\text { Rogers \& } \quad \text { Tibben- } \\
\text { Lembke (2001); Bai and } \\
\text { Sarkis (2013); } \text { Genchev } \\
(2009)\end{array}$ \\
\hline $\begin{array}{l}\text { F3 } \\
\text { Time value of } \\
\text { returned goods }\end{array}$ & $\begin{array}{l}\text { The time value of the } \\
\text { returned products. }\end{array}$ & $\begin{array}{l}\text { The product residual value, PRV, and the } \\
\text { marginal value of time, MVT. The PRV: } \\
\text { Refers to the remaining value of the product } \\
\text { after the manufacturing or the value creation } \\
\text { and the usage or the value consumption } \\
\text { phase, is determined by several factors such } \\
\text { as condition of the returned product, the } \\
\text { market for reconditioned products and } \\
\text { recycled materials, the cost structure of the } \\
\text { recovery process, and the level of } \\
\text { obsolescence. The MVT refers to the loss in } \\
\text { value per unit of time spent awaiting } \\
\text { completion of the recovery process the loss in } \\
\text { value per unit of time spent awaiting } \\
\text { completion of the recovery process } \\
\text { (Blackburn et al., 2004). }\end{array}$ & $\begin{array}{l}\text { Small loss of value } \\
\text { over time of the } \\
\text { returned products }\end{array}$ & $\begin{array}{l}\text { High loss of value over } \\
\text { time of the returned } \\
\text { products }\end{array}$ & $\begin{array}{l}\text { Blackburn et al, 2004; } \\
\text { Gobbi, 2011; Kumar et } \\
\text { al., 2007; Brodin and } \\
\text { Anderson, 2008; Guide } \\
\text { and Van Wassenhove, } \\
\text { 2003; Derimel and } \\
\text { Gökçen, 2008; Prahinski } \\
\text { and Kocabasoglu, 2006; } \\
\text { Kumar et al., 2007; Stock } \\
\text { and Mulki, 2009; Rose et } \\
\text { al., } 2002\end{array}$ \\
\hline $\begin{array}{l}\text { F4 } \\
\text { Product complexity }\end{array}$ & $\begin{array}{l}\text { The complexity of the } \\
\text { returned products. }\end{array}$ & $\begin{array}{l}\text { The relative complexity (R.C.) is defined } \\
\text { along two dimensions: the absolute } \\
\text { complexity of the product and the degree of } \\
\text { specialization required in terms of facilities, } \\
\text { equipment and personnel to carry out product } \\
\text { recovery activities. The absolute complexity } \\
\text { of the returned product can be determined } \\
\text { from the product composition, i.e. the } \\
\text { number of components and materials present } \\
\text { in the product and the way in which they } \\
\text { have been incorporated into the product } \\
\text { design. }\end{array}$ & $\begin{array}{l}\text { High product } \\
\text { complexity suggest a } \\
\text { separated set-up that } \\
\text { includes specialized } \\
\text { facilities that are able } \\
\text { to disassemble and } \\
\text { recover items } \\
\text { efficiently }\end{array}$ & $\begin{array}{l}\text { Low product } \\
\text { complexity does not } \\
\text { require specialized } \\
\text { facilities and can be } \\
\text { handled by less skilled } \\
\text { workers }\end{array}$ & $\begin{array}{l}\text { Fleischmann et al, 1997; } \\
\text { De Brito and Dekker, } \\
2003\end{array}$ \\
\hline
\end{tabular}




\begin{tabular}{|c|c|c|c|c|c|}
\hline $\begin{array}{l}\text { F5 } \\
\text { Product variation }\end{array}$ & $\begin{array}{l}\text { Product variation is } \\
\text { expressed by the number of } \\
\text { products and product } \\
\text { variants offered to the } \\
\text { customers }\end{array}$ & $\begin{array}{l}\text { Product proliferation, skillset of employees, } \\
\text { local storage space. }\end{array}$ & $\begin{array}{l}\text { High product } \\
\text { variation results in } \\
\text { higher process } \\
\text { complexity, which is } \\
\text { best handled in a } \\
\text { separated set-up }\end{array}$ & $\begin{array}{l}\text { Low product variation } \\
\text { decreases the } \\
\text { complexity enabling } \\
\text { low-skilled workers in } \\
\text { the forward supply } \\
\text { chain to handle the } \\
\text { reverse flow }\end{array}$ & $\begin{array}{l}\text { Huang and Su (2012); } \\
\text { Asif (2011) }\end{array}$ \\
\hline $\begin{array}{l}\text { F6 } \\
\text { Volume of returned } \\
\text { goods }\end{array}$ & $\begin{array}{l}\text { The volume of products to } \\
\text { be entered into the return } \\
\text { stream }\end{array}$ & $\begin{array}{l}\text { Several quantitative models have been } \\
\text { presented for forecasting the volume of } \\
\text { returned goods. }\end{array}$ & $\begin{array}{l}\text { If volume is high the } \\
\text { economies of scale } \\
\text { suggest building a } \\
\text { separate efficient } \\
\text { facility is most } \\
\text { advantageous }\end{array}$ & $\begin{array}{l}\text { Low volume does not } \\
\text { facilitate feasible use of } \\
\text { separate facilities }\end{array}$ & $\begin{array}{l}\text { Kumar et al., 2014; Liang } \\
\text { et al., 2014; Ma and Kim, } \\
\text { 2016; Clottey et al., 2012; } \\
\text { Krapp et al., 2013; Li et } \\
\text { al., 2010; Shankar, 2015) }\end{array}$ \\
\hline
\end{tabular}


The literature review proposes that all six contextual factors influence the degree of combination of the logistic flows. We propose a method to determine these factors and an organization's position in regard to the degree of combination; first using a qualitative and then a quantitative approach.

\section{Case study research design}

The overall purpose of the paper is to examine the most advantageous degree of combination between the firm's forward logistics and reverse logistics (RL). Using the contingency perspective, which assumes that an entity performs best when aligned with its context, the literature review has developed the set of contextual factors that constitute this context for a firm's reverse logistics. The contextual factors determine how the firm's reverse logistics is best aligned with its context. The paper operationalizes the concept of context-alignment as "the most advantageous degree of combination between the firm's forward and reverse logistics".

To validate the framework the paper conducts a case single study. The purpose of the case study is twofold: to develop the set of contextual factors in the literature review and possibly to identify further factors not captured in extant literature. To fulfill this purpose the case study has two overall objectives: 1) to assess the case firm's current degree of combination between forward and reverse logistics and 2) to identify the degree of combination that the contextual factors point to as most advantageous. In addition to the two overall objectives, the study examines which specific actions that can close the gap between current and most advantageous degree of combination and the financial benefits resulting from closing the gap.

The two overall objectives require detailed and rich contextual information. The case study method, and the single case study in particular, facilitates the collection and analysis of data that with the required degree of detail. The complexity of e.g. assessing a firm's current degree of combination is too high for a survey and would require an insurmountable amount of research if conducted at 8-12 case firms. According to Barrat et al. (2011) case study research enables researching a focused phenomenon with contextually rich data acquired from bounded real-world settings. In addition, case studies allow the examination of industrial practice and enables deep understanding of a phenomenon's nature and complexity (Meredith, 1989; Voss et al., 2002). The subject of forward and reverse logistics has been studied before through the lens of case study research (e.g. Jaaron and Backhouse, 2016).

\subsection{The case firm}

The case firm is a large northern European telecommunications firm operating in most of northern European countries. The firm has a large forward flow of primarily electronic items and devices, as well as a considerable reverse item flow. Items vary significantly in size, weight, value, technical complexity, amount of items in the flow, etc. The firm's RL includes a separate repair facility, which repairs and reinserts high-value items into the firm's forward flow. In addition, the firm's RL takes back returned items from the firm's own retailers and external partners in the firm's distribution network. Returned items include defective items, end-of-use items, items returned due to buyers' remorse, and items returned for other reasons. The specific nature of the firm's RL is described a part or the analysis pertaining to the case study's two overall objectives. All logistical activities in the firm are organized under the head of the operations function that handles all delivery and take-back of the items, which enable the telecommunications solutions the firm sells to both businesses and consumers.

The study has chosen this case firm because of the size and complexity of reverse flows, and because the firm has distinct recovery functions within the firm's own organization. With these criteria fulfilled, the study can analyze the total set of contextual factors as well as the firm's end-to-end reverse flow. 


\subsection{Data collection methods}

The analysis is based on the information gathered through a number of different sources. Two of the authors where physically present on a daily basis at the firm's head office for a period of five months and had full access to all personnel as well as archival records. The data collection efforts included ample opportunity for verification and cross-validation of information, which the two embedded authors ensured the use of continuously throughout the five month stay at the firm. The two primary data collection methods where interviews and informal conversations, which were conducted on a daily basis both before and after interviews. In addition, the study applied written documents, quantitative reports, and other objective data as sources of evidence.

\subsubsection{Interviews}

The study conducted 14 formal interviews. Figure 3 shows the interviewees within the organization of the firm's operations function. In addition to the interviewees within the operations function, the study interviewed a manager in one of the firm's retail stores. " $2 \mathrm{x}$ " indicates two interviews, while the dotted lines indicate the reporting lines to other departments within the case firm.

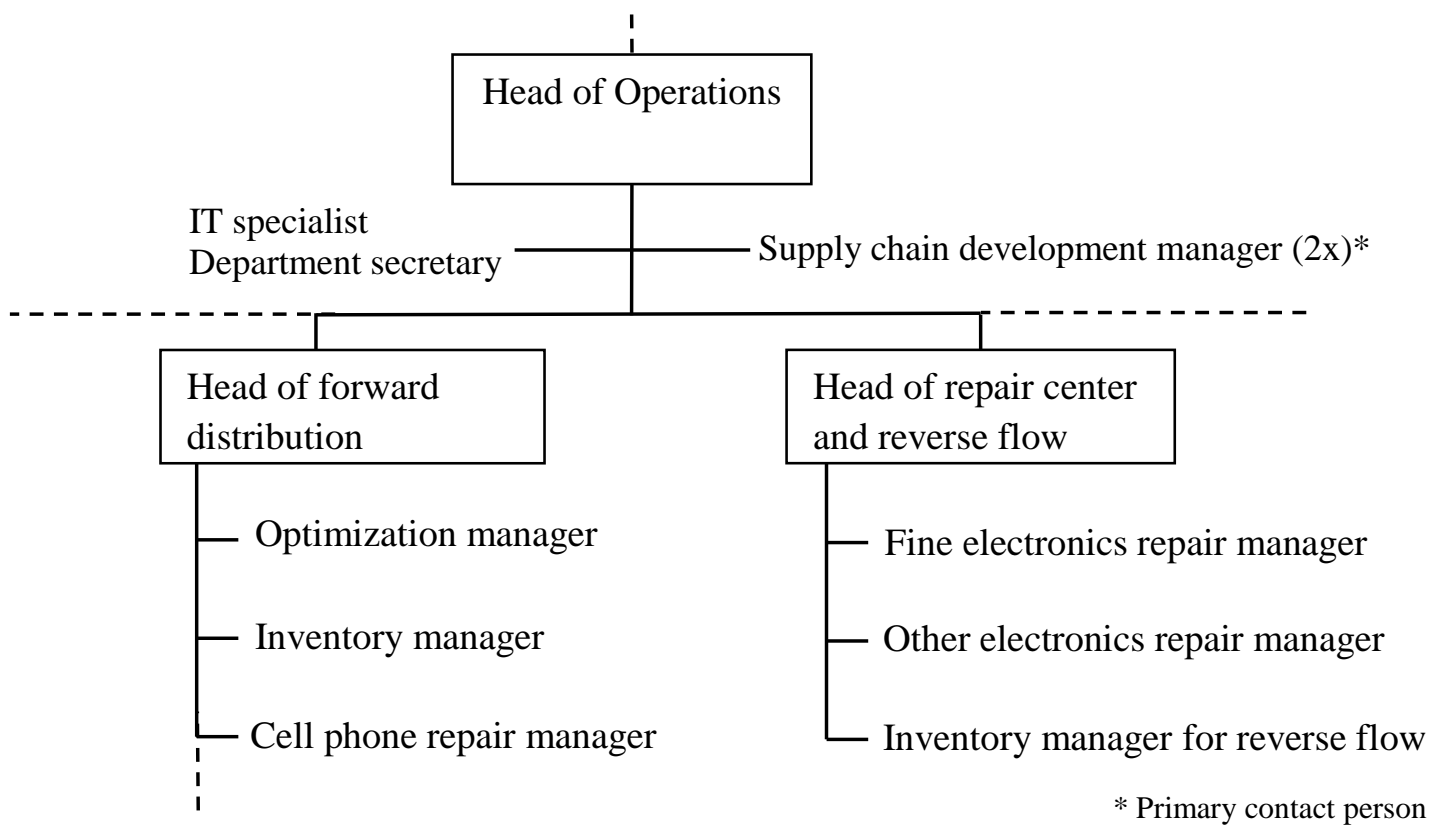

Figure 3: The set of interviewees within the organisation of the firm's operations function

The interviews were conducted using Kvale's (1997) two archetypical interviewer roles: the traveler and the miner. The traveler interviews applied open-ended interview guides with predefined themes derived from literature, while the miner interviews used structured interviews with the aim of collecting specific information or detailed knowledge. This interview method corresponds to the funnel strategy introduced by Mandel (1974). As mentioned earlier the two overall goals in all interviews were 1) to assess the case firm's current degree of combination between forward and reverse logistics and 2) to identify the degree of combination that the contextual factors point to as most advantageous. The set of interviewees where specifically selected based on their roles in and knowledge of the firm's reverse and forward logistics. Multiple respondents were interviewed because individual interviewees did not possess all the required knowledge (Voss et al., 2002). The weight of the interview themes as well as the specific questions asked varied depending on the position and knowledge of each informant. While some 
interviews focused on mapping forward flows, others concerned product and product portfolio complexity, repair policies, and assessments of the length of time items are held in inventory. Finally, some interviews focused on RL flows. Examples of subjects discussed during interviews were which facilities that are parts of the reverse logistics structure and what role they play, where and through which facilities the reverse flow streams, the volume in forward and reverse flows, and the time items spend in the return process. Some interviewees pointed at other interviewees and thus the study was able to reach information saturation.

\subsubsection{Other sources of evidence}

While the formal interviews were important sources of information in the beginning of the study, other data sources replaced interviews' importance as time passed and the two embedded authors gained insight into the case organization and formed relationships with key informants. The study's two embedded authors had informal conversations daily with relevant persons in the case firm's organization, they were able to collect archival records as needed in the form of e.g. inventory records, records over flow amounts, etc., and they were able to personally observe operations and artifacts in all relevant facilities and sites (e.g. the case firm's repair and recovery centers, forward and reverse inventories, and distribution centers as well as visits with retailers).

\subsection{Method of analysis}

The purpose of the analysis it to assess how well the case firm's current degree of combinations matches the degree of combination that the contextual factors deem most advantageous. Figure 4 illustrates this purpose.
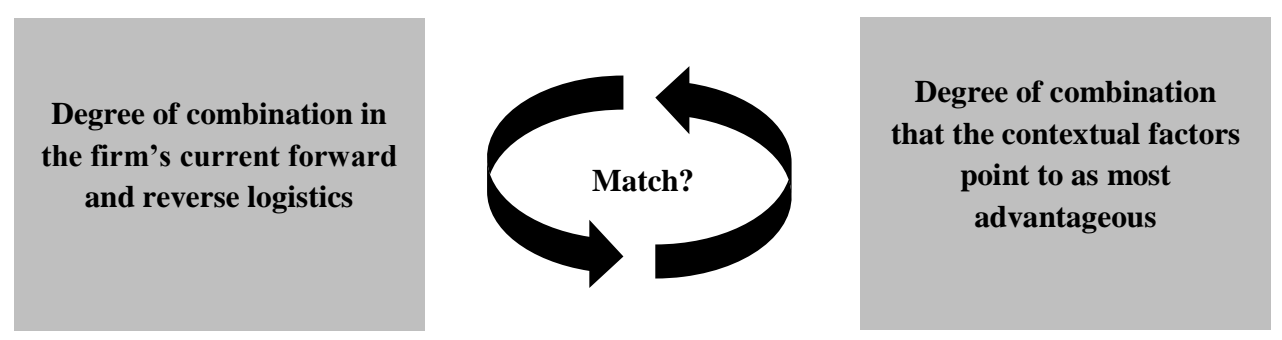

Figure 4: Analysis objective: To determine whether the firm's current degree of combination matches the stance on the contextual factors

To determine the case firm's current degree of combination, the study examines the firm's current forward and reverse product flows. Following the literature review the study examines whether facilities are separated or combined, whether forward and reverse logistics employ staff dedicated to each operation, whether transportation modes differ for each operation, and whether the two flows are managed by two distinct management teams. The two embedded authors have conducted the analysis using data from interviews, informal conversations, and objective data. In addition, the study has conducted a deep-dive analysis of one particular item, which is chosen because the item has the largest reverse flow volume. The assessment, which is qualitative in nature, results in the assessment of a degree of combination of the firm's current forward and reverse logistics. It should be noted that it is not possible to make a quantitative analysis of the firm's current degree of combination using the method described in this sections as the contextual factors are assumed to be invariant. There would therefore not any difference in the degree of combination between the assessment of current degree and the most advantageous degree as these two assessments would be based on unchanged contextual factors. 
To determine the case firm's most advantageous degree of combination, the study employs a method that mixes a qualitative assessment of whether the contextual factors point towards separation or combination with a quantitative assessment of each contextual factor's impact on the most advantageous degree of combination. This mixed approach, which is inspired by Cross (2000), assesses the most advantageous degree of combination on a scale from 0 to $100 \%$, where $100 \%$ is combination to the fullest possible degree. As input variables to the assessment, the method uses the magnitude of each contextual factor, i.e. the relative impact and direction of each contextual factor. The relative impact and direction of contextual factors are idiosyncratic to each firm.

The relative impact of each contextual factor is assessed by measuring each factor against all other factors. From these direct comparisons the relative impact of each factor emerges. Table 3 in the paper's results section illustrates the method. For each factor in Table 3 the column "Score" adds the score. This impact is then translated into a relative impact by determining the score factor has relative to the total score of all factors. The column "Separation or combination" indicates with either -1 or +1 the direction of each factor. Using expression (1) the study can assess the most advantageous degree of combination. The expression includes normalization, so results range within 0 and 1 .

$$
\text { Degree of Combination }=\left(\frac{\left.\left(\sum \text { (relative weight }\right) *(\text { Separation or Combination })\right)+1}{2}\right) * 100 \%
$$

The expression results in a number between 0 and $100 \%$, where $0 \%$ indicates that complete separation as the most advantageous configuration, while $100 \%$ indicates full combination as the most advantageous configuration. The overall framework including contextual factors as well as the mathematical expression will be validated and further detailed through the case study.

\subsection{Validity of collected data}

For review of the interviews, the study uses the condensation principle proposed by Malterud (2012), which revolves around extracting only the most essential points from the interviews. The embedded authors take notes, clean the notes, and have them validated by each interviewee. The condensation is started during the interviews as only notes were taken. To assure reliable data, the interview data is coded by two independent persons when necessary. This is the case in particular when determining the case firm's stance on the six contextual factors. Generally, the embedded authors make sure to avoid some of the problems normally associated with a case study based methodology, e.g. the lack of rigidity (Meredith, 1998). The research relies on multiple data sources within the case firm, allowing the use of triangulation to find converging themes and lines of inquiry (Voss et al., 2002). Finally, the results from the case study are presented to managers and employees in the case firm to validate results. Saturation was achieved as the researchers got access to all required data and information.

\section{Case study findings}

This section presents case study findings. First, the case is presented and then a qualitative analysis of the contextual factors this is followed by a brief description of its current structure and flows. Finally, a quantitative analysis is described in order to determine the optimal degree of combination and separation of return and forward logistics for the case company on the scale shown in figure 1. Based on these analyses we conclude what the most optimal degree of combination would be for the case company. The case study is concluded with suggested changes needed for the case company to move towards the most optimal degree of combination.

\subsection{The case firm}


The case firm is a Scandinavian firm with a nationwide network of stores selling a wide range of consumer electronics, e.g. mobile phones, computers, and modems for private customers as well as providing equipment for the ICT-infrastructure of firms (patch panels, racks, and servers). For confidentiality the firm is labelled Elex A/S. The firm has a number of field service technicians, which uses a number of local field inventories to restock their vehicles and drop off products that enter the return logistics process. The volume of returned goods is on average $7 \%$ of the forward flow (the forward flow handles around 13 million units. Of these are around 800.000 units returned and thereby become part of the return flow). The amounts of returned goods vary depending on product-type.

\subsection{Case analysis}

The case analysis will first evaluate the case company's current position on the conceptual scale of the degree of combination. Second, the analysis evaluates which degree of combination the contextual factors point to as most advantageous.

The data reveals that reverse logistics facilities are physically and geographically separated from the firm's forward logistical facilities. These forward and reverse flows intercept downstream at the service technicians' local field inventories. The organization and management of the two flows are highly separated as illustrated in Figure 5. Hence Elex A/S supply chain is characterized by separated forward and reverse logistic amounting to a low degree of combination. The result of the qualitative analysis of the current state of Elex A/S is a degree of combination ranging between $5 \%$ and $10 \%$, which is visualized in Figure 5.

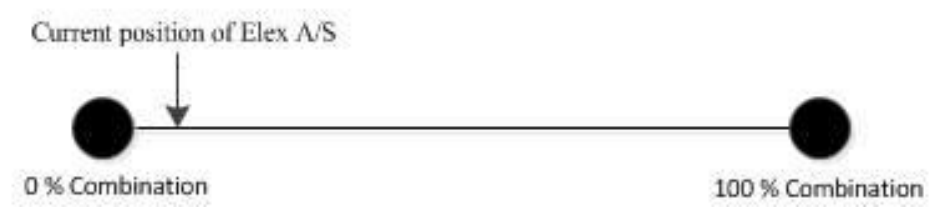

Figure 5: Elex A/S current position on the conceptual scale

As the methodology described, the analysis of contextual factors is a mix of a qualitative and quantitative approach. Table 2 summarizes the qualitative analysis of contextual factors as they apply the case firm. The analysis shows contextual factors pointing in both directions vis-à-vis the most advantageous degree of combination. Factors F1 is inconclusive, while F2 simply indicates the ability to operate both separated and combined configurations. F3 and F6 point towards combination, while F4 and F5 point towards separation. To achieve a more precise result, the analysis applies the quantitative method detailed in the methodology section.

Table 2: Summary of the Qualitative Case Analysis

\begin{tabular}{|l|l|c|}
\hline \multicolumn{1}{|c|}{ Contextual Factor } & \multicolumn{1}{|c|}{ Remarks to the Case Analysis } & $\begin{array}{c}\text { Separation or } \\
\text { Combination }\end{array}$ \\
\hline $\begin{array}{l}\text { Strategic contribution of } \\
\text { reverse logistics (F1) }\end{array}$ & $\begin{array}{l}\text { The business and logistics strategies of the case firm } \\
\text { focuses both on service improvements as well as cost } \\
\text { reductions. }\end{array}$ & Inconclusive \\
\hline $\begin{array}{l}\text { Skills in managing bi- } \\
\text { directional flows (F2) }\end{array}$ & $\begin{array}{l}\text { The managerial competences of the case firm allow for } \\
\text { combination of forward and reverse logistics. }\end{array}$ & $\begin{array}{c}\text { Combination or } \\
\text { separation }\end{array}$ \\
\hline
\end{tabular}




\begin{tabular}{|l|l|c|}
\hline $\begin{array}{l}\text { Time value of returned } \\
\text { goods (F3) }\end{array}$ & $\begin{array}{l}\text { The firm distributes and sells electronics. The time } \\
\text { value of these products is high. }\end{array}$ & Combination \\
\hline Product complexity (F4) & $\begin{array}{l}\text { Products are complex. It is, however, possible to sort } \\
\text { the products according to product type locally. }\end{array}$ & Separation \\
\hline Product variation (F5) & $\begin{array}{l}\text { The product portfolio is varied even though all the } \\
\text { products are in the product category of "electronics" }\end{array}$ & Separation \\
\hline $\begin{array}{l}\text { Volume of returned goods } \\
\text { (F6) }\end{array}$ & $\begin{array}{l}\text { In total the volume of returned goods is relatively } \\
\text { small compared to benchmarks from other industries } \\
\text { (Rogers \& Tibben-Lembke, 1998) }\end{array}$ & Combination \\
\hline
\end{tabular}

Table 3 shows the quantitative case analysis for Elex A/S. Initially, the researchers conducted the comparisons, and the results were subsequently adjusted and validated by managers and employees from ELEX A/S. Example of the use of the table: In the intersection between row F3 and column F6 the study must decide whether F3 or F6 has the greatest relative impact on the firm's most advantageous degree of combination. Because the time value of the firm's products decreases quickly in this industry, F3 has a higher impact on the most advantageous degree of combination than the product complexity. Therefore, in this particular intersection F3 has the largest impact, and the correct score of one is therefore given to F3 (the factor in the row).

Table 3: Quantitative Case Analysis for Elex A/S

\begin{tabular}{|c|c|c|c|c|c|c|c|c|}
\hline & F1 & F3 & F4 & F5 & F6 & $\begin{array}{c}\text { Separation } \\
\text { or } \\
\text { combination }\end{array}$ & Score & $\begin{array}{c}\text { Relative } \\
\text { impact }\end{array}$ \\
\hline F1 & & 1 & 1 & 1 & 1 & 0 & 4 & 0,40 \\
\hline F3 & 0 & & 1 & 1 & 1 & 1 & 3 & 0,30 \\
\hline F4 & 0 & 0 & & $1 / 2$ & $1 / 2$ & 1 & 1 & 0,10 \\
\hline F5 & 0 & 0 & $1 / 2$ & & $1 / 2$ & -1 & 1 & 0,10 \\
\hline F6 & 0 & 0 & $1 / 2$ & $1 / 2$ & & -1 & 1 & 0,10 \\
\hline
\end{tabular}

Using formula (1) from the methodology section, the researchers calculated the most advantageous degree of combination. The result, which is $60 \%$, indicates the range of $50-70 \%$ as the most advantageous a degree of combination. Consequently, the case firm should adopt a significantly higher degree of combination between the forward and reverse logistics. Figure 6 illustrates the difference between current and most advantageous degree of combination.

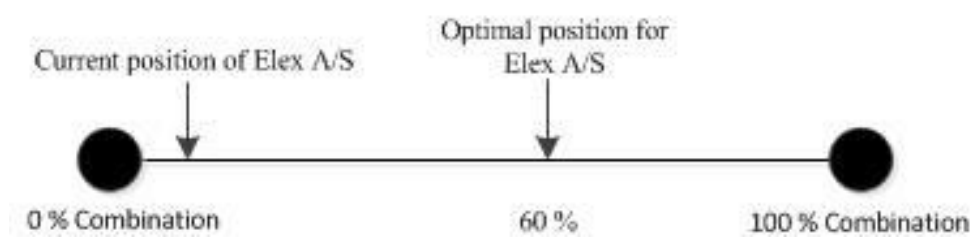




\subsection{Suggested changes for Elex A/S}

To close the gap between current and most advantageous degree of combination, the study suggests implementing a number of specific changes. As the literature suggests, changes that lead to a higher degree of combination concern logistics facilities, staff, transportation modes, and management teams. Table 4 details the suggested changes.

\section{Table 4: Suggestions for changes of Elex A/S}

\begin{tabular}{|l|l|}
\hline \multicolumn{2}{|c|}{ Suggested changes } \\
\hline $\begin{array}{l}\text { Move the inventory holding core products and } \\
\text { components from a separate geographical location } \\
\text { to be in the same buildings ass the forward flow }\end{array}$ & $\begin{array}{l}\text { This move enables utilization of the currently idle } \\
\text { storage capacity at the forward flow's central } \\
\text { inventory. In addition, the move reduces transport } \\
\text { costs and time between reverse and forward } \\
\text { inventories }\end{array}$ \\
\hline $\begin{array}{l}\text { Move the repair facility from a separate } \\
\text { geographical location to be in the same buildings } \\
\text { ass the forward flow }\end{array}$ & $\begin{array}{l}\text { This move reduces transportation cost between } \\
\text { electronics center and central storage }\end{array}$ \\
\hline Combined IT-system & $\begin{array}{l}\text { Improves transparency between the two flows and } \\
\text { number of products at each location }\end{array}$ \\
\hline Local sorting & $\begin{array}{l}\text { Retailers sort by type and technicians sort at drop- } \\
\text { points. Waste will be sorted locally and reduce } \\
\text { transportation cost }\end{array}$ \\
\hline Reduction of time consumption & $\begin{array}{l}\text { Reduction of reverse logistic delivery time to the } \\
\text { central inventory, which will reduce the number } \\
\text { of units in the flow }\end{array}$ \\
\hline
\end{tabular}

In addition to the changes noted in the table, the study suggests combining management of forward and reverse logistics and train staff to work in both areas to increase personnel flexibility enabled by job rotation. To implement this change successfully it is important to ensure the staff has the right competences for all the tasks and that managers have support and knowledge of how to manage and lead employees from both logistics flow. The study conducted a cost-benefit analysis of the changes and found that the suggested changes result in a positive net result.

\section{Contributions to theory and practice}

This section is divided into two subsections concerning theoretical and practical contributions.

\subsection{Contribution to theory}

Traditionally, RL-literature has viewed reverse product flows as "problems" that needed to be handled and thus proactive assessment of the most advantageous degree of combination is rarely conducted. As the industrial interest in RL and the body of knowledge regarding RL has grown, the question of how to 
structure the RL vis-à-vis the firm's forward logistics has become a critical issue. By contrast, the vast majority of extant literature does not address whether RL is most advantageous in a combined or separated configuration. This paper's key contribution to theory is the identification of a comprehensive set of contextual factors that is necessary for the determination of the most advantageous degree of combination. Furthermore, the paper demonstrates how to conduct a qualitative as well as a quantitative assessment of a given firm's current degree of combination and the degree of combination that the context of the firm's RL points to as most advantageous. Furthermore, the use of a qualitative methodology represents a novel approach for these types of research studies. The paper therefore contributes to the body of RL-knowledge in several ways:

- A comprehensive identification of key contextual factors determining the appropriate degree of combination within reverse logistics

- A quantitative analysis of contextual factors to determine the current and optimal degree of combination for return logistics.

- Development of a decision making framework useful for practitioners regarding the current and optimal structure of their RL flow.

The use of a qualitative case study to illustrate, test and further frame the developed framework

\subsection{Contribution to practice}

The paper provides managers with a concrete framework to assess whether the firm has chosen the advantageous degree of combination between forward and return logistics. The framework enables managers to include multiple factors in their analysis instead of only focusing on a single factor at a time, often focusing on lowest costs. Furthermore, the paper also provides an easy way of estimating the most advantageous degree of combination. The framework can show managers their firm's right position on the scale from $0 \%$ to $100 \%$ combination. When a given manager has a determined the most advantageous degree of combination, the manager has an insight which care can be used to change RL-set-up of the firm, i.e. seek a higher or lower degree of combination. Once the direction is set, the firm should aim for improvements within physical, technical and organizational issues. For physical improvements the focal point is the physical network configuration of the logistical flows. Technical improvements typically relate to IT-integration (e.g. shared systems, sharing of storage space, sorting facilities, etc.), while organizational improvements relate to the division of labor, management competences and roles and responsibilities within the organization.

\subsubsection{Framework application procedure}

To use the framework, the study suggests an iterative approach as illustrated in figure 7. 


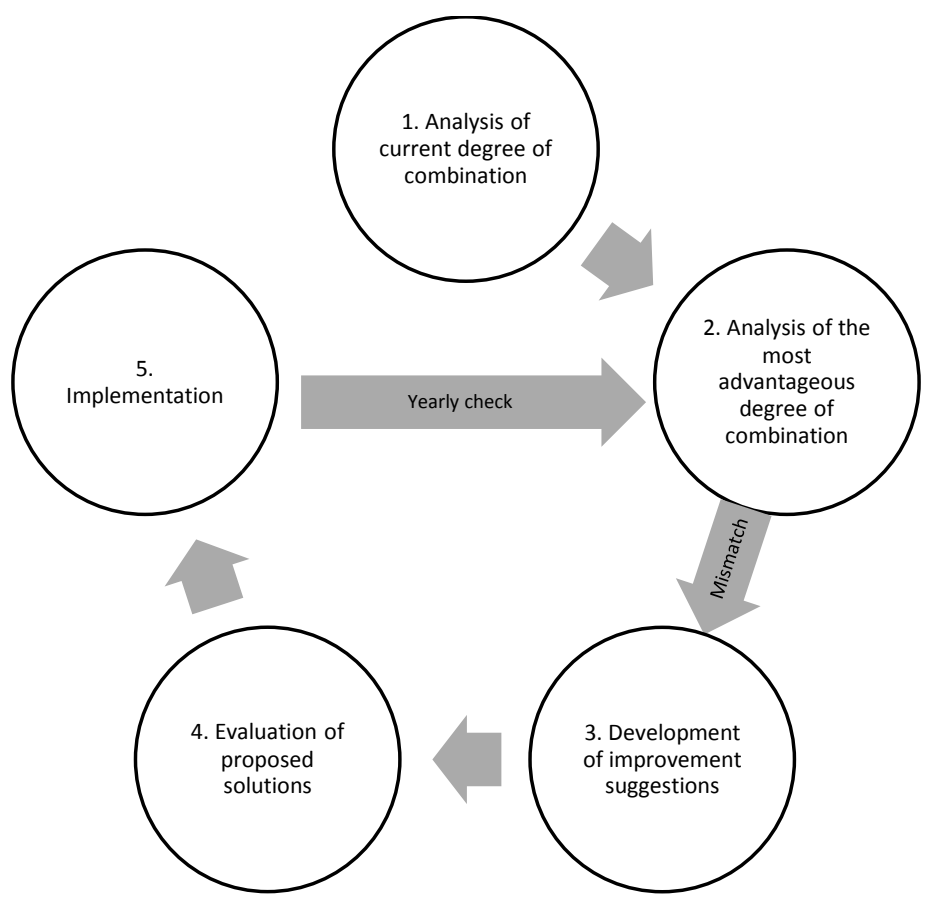

Figure 7: Framework application procedure

The procedure has five steps and a suggested yearly cycle to ensure the degree of combination is still fulfilling the company's business needs:

Step 1: Determine the current degree of combination (i.e. the current position on the conceptual scale). This step is done once and hereafter simply kept up to date.

Step 2: Determine the most advantageous degree of combination for the company using the set of six contextual factors

The first time this is done it will require more effect and it is suggested that stakeholders across the company are involved. It is suggested that the degree of combination is assessed regularly, i.e. on a yearly basis, to ensure that the current degree of combination is still the optimal one.

Step 3: Unless the factor analysis and current RL-set-up match completely, set the direction for improving the degree of combination and suggest specific improvement

If there is a match between the factor analysis and current RL-set-up then nothing is done till the next yearly review.

Step 4: Evaluate suggestions using cost-benefit analyses

It is recommended that all key stakeholders across the company are involved to ensure both quantitative and qualitative benefits and costs are considered.

\section{Step 5: Implement suggestions}

Due to the yearly review it is recommended that the company doesn't make too many radical changes within a single year as each change needs time to be implemented and be accepted by the employees and become a part of the organizational processes, procedures and culture. 


\section{Conclusions, limitations, and suggestions for further research}

While reverse Logistics (RL) has gained increased focus, the practical tools to evaluate the degree of combination of the reverse and forward logistics are missing. The purpose of this paper is therefore to identify contextual factors that determine the most advantageous degree of combination for the firm. The study has identified six contextual factors, which all contribute to deciding the degree of combination. A scale was developed showing a continuum between the two extremes of 0\% and 100\% combination. Based on these findings the paper has developed a decision making framework which practitioners can use to determine the most advantageous configuration for their firm's RL.

Extant RL-theory usually defines a problem where the RL setup under investigation is defined by a set of assumptions. The degree of combination is usually among these assumptions although neither explicitly stated nor critically evaluated. The paper contributes to RL-theory by examining the key contextual factors that influence determine the most advantageous degree of combination and proposes a decision making framework useful for practitioners.

One of the limitations to the theoretical framework is the absence of environmental impact (Rubio and Jimenez-Parra, 2014; Zhao et al., 2008). Once the environmental impacts pertaining to each contextual factor have been incorporated into the framework, it would be up to the firm to evaluate the trade-offs between the economic and the environmental impacts of each factor. Moreover outsourcing is not considered as an option for optimization of the supply chain configuration as the framework assumes that ownership of all processes is in the hand of the firm. However, the effect of outsourcing product recovery activities can lead to cost reduction (Ordoobadi, 2009), increased operational efficiency and improved customer service level that, consequently, may help the firm achieve competitive advantage over its competitors (Sahay and Mohan, 2006; Pagell et al., 2007). In leaving out outsourcing from the contextual factors, these advantages of outsourcing, which may affect the optimal supply chain configuration of the firm, are not being taken into consideration.

Future research can examine the exhaustiveness of contextual factors. Jaaron and Backhouse (2016) suggest customer demands as pivotal to reverse logistics design as well as the learning from reverse product flows. Furthermore, analyses can assess how environmental impact related to each contextual factor can be incorporated into the framework to achieve a holistic view of the key drivers for implementing reverse logistics. In addition, future research and development can also attempt to validate the framework in other firms and industries. Finally, research is needed to strengthen and further develop the framework.

\section{References}

Adenso-Diaz, B., P. Moreno, E. Gutierrez and S. Lozano, (2011), "An analysis of the main factors affecting bullwhip in reverse supply chains", International Journal of Production Economics, Vol. 135, pp. 917-928.

Agrawal, S., R. K. Singh, Q. Murtaza, (2015), “A literature review and perspectives in reverse logistics”, Resources, Conservation and Recycling Vol. 97, pp. 76-92.

Antonyová A., Antony, P., \& Soewito, B, (2016), "Logistics Management: New Trends in the Reverse Logistics", Journal of Physics: Conference Series, Vol. 710: 012018, pp.1-10.

Aras N, Boyaci T, Verter V., (2010), "Designing the reverse logistics network", Closed-loop supply chains: new developments to improve the sustainability of business practices, Auerbach Publications, pp. 67-97

Asif, R., (2011), "Reverse Logistics: RFID the key to optimality", Journal of Industrial Engineering and Management, Vol.2, pp.281-300. 
Bai, C. and J. Sarkis, (2013), "Flexibility in reverse logistics: a framework and evaluation approach", Journal of Cleaner Production, Vol.47, pp.306-318.

Barfod, M. B., K.B. Salling and S. Leleur, (2011), "Composite decision support by combining costbenefit and multi-criteria decision analysis", Decision Support Systems, Vol.51, pp.167-175.

Barney, J. B., (1991), "Firm resources and sustained competitive advantage", Journal of Management, Vol.17, pp. 99-120.

Blackburn, J.D., V. D. R. Guide, G. C. Souza, and L. N. van Wassenhove, (2004), "Reverse Supply Chains for Commercial Returns", California Management Review, Vol. 46, No.2, pp.6-22.

Brodin, M.H. and Anderson, H., (2008), "Recycling calls for revaluation", Supply Chain Management: An International Journal, vol.13, No.1, pp. 9-15

Brynjolfsson, E., Hu, Y. J., \& Simester, D. (2011). "Goodbye Pareto Principle, Hello Long Tail: The Effect of Search Costs on the Concentration of Product Sales", Management Science, Vol.57, No.8, pp.1373-1386.

Christopher, M., (2011), Logistics \& Supply Chain Management, Pearsons Education Limited (4 ${ }^{\text {th }}$ edition).

Clottey, T., Benton, W. C., \& Srivastava, R., (2012), "Forecasting Product Returns for Remanufacturing Operations", Decision Sciences, Vol. 43, No.4, pp.589-614.

Cross, N., (2000), Engineering design methods: Strategies for product design, Wiley.

Brito, M.P. de, and Dekker,R., (2009), Reverse Logistics - a Framework, Springer.

Demirel, N., \& Gökçen, H., (2009), "A mixed integer programming model for remanufacturing in reverse logistics environment”, International Journal of Advanced Manufacturing Technology, Vol.39, No.11-12, pp. 1197.

Difrancesco, R.M., and A. Huchzermeier, (2016), "Closed-loop supply chains: a guide to theory and practice", International Journal of Logistics Research and Application, Vol. 19, No. 5, pp.443464.

ElMaraghy, W., ElMaraghy, H., Tomiyama, T., \& Monostori, L. (2012). “Complexity in engineering design and manufacturing”. CIRP Annals - Manufacturing Technology, Vol. 61, No. 2, pp.793814.

ElMaraghy, H., Schuh, G., ElMaraghy, W., Piller, F., Schönsleben, P., Tseng, M., \& Bernard, A. (2013). "Product variety management". CIRP Annals - Manufacturing Technology, Vol. 62, No.2, pp.629-652.

Ene, S. and N. Öztürk, (2013), "Open loop reverse supply chain network design”, Procedia - Social and Behavioral Sciences, Vol.109, pp.1110-1115.

Ferguson, M.E. and Souza, G.C., (2010), Closed-Loop Supply Chains: New Developments to Improve the Sustainability of Business Practices, CRC Press, Boca Raton, FL,.

Fisher, M., (1997), "What is the right supply chain for your products?", Harvard Business Review, Vol.75, No.2, pp. 105-16.

Fleischmann, M., Bloemhof Ruwaard, J. M., Dekker, R., van der Laan, E., van Nunen, J. A. E. E., \& Van Wassenhove, L. N., (1997), "Quantitative models for reverse logistics: A review", European Journal of Operational Research, Vol.103, No.1, pp. 1-17.

Fleischmann, M., H.R. Krikke, R. Dekker, and S. D. P. Flapper, (2000), "A characterization of logistics networks for product recovery", Omega, No.28, pp. 653-666.

Genchev, S.E., (2009), "Reverse logistics program design: A firm study”, Business Horizons, No.52, pp. 139-148.

Genchev, S. E., Glenn Richey, R., \& Gabler, C. B. (2011). Evaluating reverse logistics programs: a suggested process formalization. The International Journal of Logistics Management, 22(2), 242263. 
Gobbi, C., (2011), "Designing the reverse supply chain: the impact of the product residual value", International Journal of Physical Distribution \& Logistics Management, 41, No.8, pp. 768 - 796.

Govindan, K., and H. Soleimani, (2016), “A review of reverse logistics and closed-loop supply chains: a Journal of Cleaner Production focus", Journal of Cleaner Production, pp.1-14.

Govindan, K., H. Soleimani, and D. Kannan, (2015), "Reverse logistics and closed-loop supply chain: A comprehensive review to explore the future", Vol.240, No.3, pp. 603-626.

Guide, V.D.R. (2000), "Production planning and control for remanufacturing: industry practice and research needs", Journal of Operations Management, Vol. 18, No. 4, pp.467-483.

Guide, V. D. R., and Van Wassenhove, L. N., (2002), “The reverse supply chain”, Harvard Business Review, 80, No.2, 25-26.

Guide, V. D. R., Jayaraman, V., \& Linton, J. D., (2003), "Building contingency planning for closed-loop supply chains with product recovery”, Journal of Operations Management, 21, No.3, pp. 259279.

Guide, V.D.R. Jr and Van Wassenhove, L., (2003), Business Aspects of Closed-loop Supply Chains, Carnegie Mellon University Press, Pittsburgh, PA.

Guide, V. D. R., Souza, G. C., Van Wassenhove, L. N., \& Blackburn, J. D., (2006), "Time value of commercial product returns.”. Management Science, 52, No.8, pp. 1200-1214.

Guide, V. D. R., and L. N. Van Wassenhove, (2009), “The Evolution of Closed-Loop Supply Chain Research." Operations Research, Vol.57, No.1, pp. 10-18.

Guizzi, G., Revetria, R., Chiocca, D., and Romano, E., (2012), "A dynamic milk run in WEEE reverse logistics", Advances in Computer Science, pp.478-484.

Hayes, R. H., Pisano, G. P., Upton, D. M., and Wheelwright, S. C. (2005). Operations, Strategy, and Technology: Pursuing the Competitive Edge. New York, NY: John Wiley \& Sons

Hahler, S., \& Fleischmann, M., (2013), "The value of acquisition price differentiation in reverse logistics.", Journal of Business Economics, Vol. 83, No.1, pp. 1-28.

Huang, S., and J.C.P. Su, (2012), "Impact of product proliferation on the reverse supply chain", Omega, Vol. 41, No.2013, pp. 626-639.

Hu, S.J., Ko, J. Weyand, L., ElMaraghy, H.A., Lien, T.K., Koren, Y., Bley, H., Chryssolouris, G., Nars, N., Shpitalni, M. (2011). "Assembly system design and operations for product variety", CIRP Annals - Manufacturing Technology, Vol. 60, pp.715-733.

Huscroft, J. R., Hazen, B. T., Hall, D. J., Skipper, J. B., \& Hanna, J. B., (2013a), "Reverse logistics: past research, current management issues, and future directions", International Journal of Logistics Management, Vol. 24, No.3, pp. 304-327.

Joseph R. Huscroft, Benjamin T. Hazen, Dianne J. Hall, Joe B. Hanna, (2013) "Task-technology fit for reverse logistics performance", The International Journal of Logistics Management, Vol. 24, No.2, pp. 230 - 246

Jaaron, A. A.M., and Backhouse, Chris, (2016) "A systems approach for forward and reverse logistics design: Maximising value from customer involvement", International Journal of Logistics Management, Vol. 27, No.3, pp.947 - 971

John, S. T., Sridharan, R., \& Kumar, P. R. (2017). Multi-period reverse logistics network design with emission cost. International Journal of Logistics Management, The, 28(1), pp. 127-149

Krapp, M., Nebel, J., \& Sahamie, R., (2013), "Forecasting product returns in closed-loop supply chains", International Journal of Physical Distribution and Logistics Management, Vol. 43, No.8, pp. 614-637.

Kumar, V., Shirodkar, P.S., Camelio, J.A. and Sutherland, J.W., (2007), "Value flow characterization during product lifecycle to assist in recovery decisions", International Journal of Production Research, Vol.45, No.18/19, pp. 4555-72. 
Kumar, D. T., Soleimani, H., \& Kannan, G., (2014), "Forecasting Return Products In An Integrated Forward/Reverse Supply Chain Utilizing An Anfis", International Journal of Applied Mathematics and Computer Science, Vol.24, No. 3, pp. 669-682.

Krikke, H., Hofenkc, D. \& Wangb, Y. (2013), "Revealing an invisible giant: A comprehensive survey into return practices within original (closed-loop) supply chains", Resources, Conservation and Recycling, Vol.73, pp.239-250

Larsen, S. B., \& Jacobsen, P., (2016), "Revenue in reverse? An examination of reverse supply chain enabled revenue streams", International Journal of Physical Distribution \& Logistics Management, Vol.46, No. 8, pp. 783-804

Lechner, A., Klingebiel, K., \& Wagenitz, A. (2011). "Evaluation of Product Variant-driven Complexity Costs and Performance Impacts in the Automotive Logistics with Variety-driven Activity-based Costing". Proceedings of the International MultiConference of Engineers and Computer Scientists, Vol. 12, pp. 16-18.

Li, H. and Womer, K., (2008), "Modeling the supply chain configuration problem with resource constraints", International Journal of Project Management, Vol.26, No.6, pp. pp. 646-54.

Liang, X., Jin, X., \& Ni, J., (2014), "Forecasting product returns for remanufacturing systems", Journal of Remanufacturing, Vol.4, No.1, pp. 1-18.

Luthans, F. \& Stewart, T.I., (1977). A general contingency theory of management. Academy of Management Review, Vol.2, No.2, pp. 181-195.

Ma, J., \& Kim, H. M., (2016), "Predictive Model Selection for Forecasting Product Returns", Journal of Mechanical Design, Vol.138, No.5, pp. 054501.

MacDuffie, J.P., Sethuraman, K. and Fisher, M.L. (1998), "Product variety and manufacturing performance: evidence from the international automotive assembly plant study. Management Science, Vol.42, pp.350-70.

Malterud, K., (2012), "Systematic text condensation: A strategy for qualitative analysis", Scandinavian Journal of Public Health, Vol.40, pp.795-805.

Mandel, J., E., (1974), “A strategy for selecting and phrasing questions in an interview”, The Journal of Business Communication, Vol.12, pp.18-23.

Marx-Gomez, J., Rautenstrauch, C., Nörnberger, A., and Kruse, R. (2002), Neuro-fuzzy approach to forecast returns of scrapped products to recycling and remanufacturing. Knowledge-Based Systems, Vol.15, No.1, pp.119-128.

Meredith, J., (1998), "Building operations management theory through case and field research", Journal of Operations Management, Vol.16, pp.441-454.

Min, H., Ko, H. J., \& Ko, C. S., (2006), “A genetic algorithm approach to developing the multi-echelon reverse logistics network for product returns", Omega-International Journal of Management Science, Vol.34, No.1, pp. 56-69.

Mollenkopf, D. A., \& Closs, D. J., (2005), “The Hidden Value in RESERVE LOGISTICS.”, Supply Chain Management Review, Vol.9, No. 5, pp. 34.

Narayana, A. S., Elias, A. A., \& Pati, K. R. (2014). Reverse logistics in the pharmaceuticals industry: a systemic analysis. The International Journal of Logistics Management, 25(2), pp. 379-398.

Ohdar, R., and P. K. Ray, (2012), "Models and Methodologies in supply chain management: Review and Reflections", IUP Journal of Supply Chain Management, Vol 9, No.4, pp. 7-45.

Ordoobadi, S. M., (2009), "Outsourcing reverse logistics and remanufacturing functions: a conceptual strategic model", Management Research News, Vol. 32, No.9, pp. 831 - 845.

Pagell, M., Wu, Zh. and Nagesh, N.M., (2007), "The supply chain implications of recycling”, Business Horizon, Vol. 50, pp.133-143.

Porter, M.E., (1980), “Competitive Strategy”, Free Press, New York, NY, ISBN 978-0-7432-6088-6. 
Porter, M. E., (1985), "Competitive Advantage: Creating and Sustaining Superior Performance", Free Press, New York, NY, ISBN 978-0-0292-5090-7.

Prahinski, C. and Kocabasoglu, C., (2006), "Empirical research opportunities in reverse supply chains", Omega, Vol.34, No.6, pp. 519-32.

Tibben-Lembke, R.S. and Rogers, D.S., (1998), "Going backwards: reverse logistics trends and practices", University of Nevada, Reno Center for Logistics Management.

Rogers, D. S., and R. Tibben-Lembke, (2001), "An examination of reverse logistics practices”, Journal of Business Logistics, Vol.22, No.2, pp. 129-148.

Tibben-Lembke, R. S., \& Rogers, D. S., (2002), "Differences between forward and reverse logistics in a retail environment”, Supply Chain Management, Vol.7, No.5, pp. 271-282.

Randall, T., and Ulrich, K. (2001). "Product variety, supply chain structure, and firm performance: analysis of the U.S. bicycle industry". Management Science, Vol.47, pp.1588-604.

Rowley, J., and F. Slack, (2004), "Conducting a literature review", Management Research News, Vol.27, No. 6, pp. 31-39.

Rubio, S. and B. Jimenez-Parra, (2014), "Reverse Logistics: Overview and Challenges for Supply Chain Management”, International Journal of Engineering Business Management, Vol.6, No. 12, pp.17.

Rose, C., Stevels, A. and Ishii, K., (2002), "Method for formulating product end-of-life strategies for electronics industry", Journal of Electronics Manufacturing, Vol.11, No.2, pp. 185-96.

Shankar, V R. R., (2015), "Survey of reverse logistics practices in manufacturing industries: an Indian context”, Benchmarking: An International Journal, Vol.22, pp. 874-899.

Sahay, B.S. and Mohan, R., (2006), "3PL: an Indian perspective', International Journal of Physical Distribution \& Logistics Management, Vol. 36, No.9, pp. 666-689.

Serdarasan, S., (2013), "A review of supply chain complexity drivers," Computers \& Industrial Engineering., vol. 66, no. 3, pp. 533-540.

Slack, N. and Lewis, M. (2002) Operations Strategy, Harlow: Pearson Education

Srai, J.S. and Gregory, M. (2008), “A supply network configuration perspective on international supply chain development", International Journal of Operations \& Production Management, Vol. 28 No. 5, pp.386-411.

Stock, J., T. Speh, and H. Shear, (2002), "Many Happy (Product) Returns”, Harvard Business Review, pp.16-17.

Stock, J. and Mulki, J., (2009), "Products returns processing: an examination of practices of manufacturers, wholesales/distributors, and retailers", Journal of Business Logistics, Vol. 30, No.1, pp. 33-62.

Tagaras, G., \& Zikopoulos, C., (2008), "Optimal location and value of timely sorting of used items in a remanufacturing supply chain with multiple collection sites.", International Journal of Production Economics, Vol.115, No.2, pp. 424-432.

Van den Honert, R.C., and F.A. Lootsma, (2000), "Assessing the quality of negotiated proposals using the REMBRANDT system”, European Journal of Operational Research, Vol.120, pp.162-173.

Voss, C., N. Tsikriktsis, and M. Frohlich, (2002), "Case research in operations management", International Journal of Operations \& Production Management, vol.22, No.2, pp. 195-219.

Wan, X., Evers, P. T., \& Dresner, M. E. (2012). "Too much of a good thing: The impact of product variety on operations and sales performance". Journal of Operations Management, 30(4), 316324. https://doi.org/10.1016/j.jom.2011.12.002

Zaarour, N., E. Melachrinoudis, M. Solomon and H. Min, (2014), “A Reverse Logistics Network Model for Handling Returned Products", International Journal of Engineering Business Management, pp.6-13. 
Zainal, Z., (2007), "Case study as research method", Jurnal Kemanusiaan, Vol.9, pp.1-6.

Zeithaml, V. A., "Rajan" Varadarajan, P., \& Zeithaml, C. P., (1988), "The contingency approach: its foundations and relevance to theory building and research in marketing", European Journal of Marketing, Vol. 22, No.7, pp.37-64.

Zhao, C., W. Liu, and B. Wang, (2008), "Reverse Logistics", in International Conference on Information Management, Innovation Management and Industrial Engineering 2008 proceedings of the international conference in Taipei, Taiwan, 2008, IEEE, Taipei, Vol.3, pp. 12-32.

Zhou, L., Xie, J., \& Lin, Y., (2010), "Forecasting returns in reverse logistics using GERT network theory", Iet Conference Publications, Vol. 565, pp.349-356. 